\title{
Basic Income and the Two Dilemmas of the Welfare State
}

\author{
Philippe Van Parijs
}

Can we avoid a social tragedy? Can we help entering the next century with our welfare states in disarray, with labour's hard-won conquests under deadly threat, and with a growing minority of citizens losing all hope of ever getting a decent job and securing a decent standard of living throughout their existence ? I believe we can, but also that it won't be easy. Both intelligence and will will be badly needed, basically to come to terms with two central dilemmas.

\section{First dilemma: fighting exploitation versus fighting exclusion}

Improving the incomes and working conditions of the poorest workers - whether directly through a statutory minimum wage and other aspects of labour law or indirectly through improving the levels of the replacement incomes granted to those out of work - has long been a central objective of our welfare states. But because exclusion from paid work is also as such a major form of deprivation, another central objective must be to fight against unemployment. The tension between these two objectives generates our first dilemma. At least under a number of (un-Keynesian) assumptions that have become realistic enough, the more you do to improve the material situation of the poorest among the workers, the scarcer the jobs become, and the more people there are who are deprived of the privilege of having one. Thus, the two objectives potentially pull it in opposite directions. And as soon as unemployment ceases to be a marginal phenomenon, this leads to an acute dilemma.

This dilemma can be highlighted by starting from the dramatic explosion of inequalities in gross earnings that has been observed in much of the Western world in the last fifteen years or so. The exact pattern of causation is disputed. But it is bound to include such factors as worlwide outlet expansion, increased competition on both labour and goods markets and the nature and distribution of the skills made more crucial by the computer revolution. In both the United States and Western Europe, the higher gross earnings have risen considerably. But at the bottom end, there is a striking difference. Owing precisely to the better social protection of both the employed and the unemployed, what has led in the United States to a sizable fall in the lower categories of earnings has led in Europe to a considerable permanent increase across cycles in the proportion of people excluded from gainful employment. The very success (however partial) of Europe's fight against exploitation is making exclusion the dominant form of social injustice. Is there a way out of this painful dilemma between the fight against exploitation and the fight against exclusion, between our concern with poverty and our concern with unemployment? Yes, there is.

Along with a growing number of people across Western Europe, I have been arguing that any realistic and desirable solution to this dilemma must involve the introduction of a comprehensive minimum income guarantee that takes the form, not of a meanstested safety net in which people get stuck as illustrated by the UK's basic social security, Germany's Sozialhilfe, France's revenu minimum d'insertion, etc. but of a genuine unconditional floor. Under various names basic income, social dividend, Grundeinkommen, reddito di 
cittadinanza, allocation universelle, etc., this idea is being proposed as a key component of the backbone of a positive progressive project for a postneoliberal, postcommunist Europe. Of course, because of the principled though partial disconnection between labour and income it implies, this proposal calls for some quite radical rethinking not least in those parties whose very name makes it clear that they regard (paid) labour as central. But contrary to what is sometimes said, it does not rely on some absurdly optimistic assumption of abundance. Nor does it give up the aim of full employment, at any rate in the important sense of trying to give everyone the possibility of doing meaningful paid work. Indeed, something like a basic income is part of any realistic strategy for achieving it.

Ever wider circles of people are beginning to see some sense in this bold claim, as they start realizing the narrow limits of what can be expected from such alternative policies as general working time reduction or active labour market policies, and as they start sharing the following crucial insights. Coupled with a corresponding reduction in all other benefits and of the net minimum wage, basic income can be viewed as an employment subsidy given to the potential worker rather than to the employer, with crucially distinctive implications as to the type of low-productivity job that is thereby made viable. Secondly, because it is given irrespective of employment status, the introduction of a basic income abolishes or reduces the unemployment trap, not only by making more room for a positive income differential between total idleness and some work, but even more by providing the administrative security which will enable many people to take the risk of accepting a job or creating their own. Thirdly, basic income can be viewed as a soft strategy for job sharing, by providing all with a small unconditional sabbatical pay, and thereby making it more affordable for many either to temporarily relinquish their job in order to get a break, go self-employed or retrain, or to durably work on a more part-time basis.

The combined effect of these three processes should lead to a far more souple working of the labour market, with significantly more stepping-stone, training-intensive, often part-time jobs. Such jobs must be paid little because they represent a risky investment on the part of the employer in a free human being who could leave any time. And they could acceptably be paid little because the pay would supplement an income to which the workers are unconditionally entitled and which therefore enables them to filter out the jobs that are not sufficiently attractive in themselves or in terms of the prospects they offer. Of course, the size of this effect will be very sensitive to the level of the basic income and to the package of labourmarket and tax-and-benefit institutional adjustments that will need to accompany its introduction. But if embedded in an appropriate package, even a modest basic income could put a halt to the growing dualization and de-moralization of our socio-economic system. Under present conditions, the indignation of the jobless who are morally and legally expected to keep looking for what many know they will never find is matched by the outrage of those who subsidize with their social security contributions the idleness of people who are overtly transgressing the rules of the game. Once it stops being utopian to believe that all those who wish to work can find a job which earns them (when added to the unconditional part of their income) enough to live on, the conditions attached to supplementary entitlements typically, unemployment benefits restricted to active job seekers can more realistically and more legitimately be expected to be enforced. The introduction of an unconditional basic income would thereby also make it possible to rehabilitate the social insurance aspect of our welfare systems. Consequently, whereas a well-intentioned gradual increase in the real level of the safety net could rightfully be feared to further disturb the working of the labour market, a well-embedded gradual lifting of the floor can be expected to address both the poverty and the unemployment problem. 


\section{Second dilemma: economic capacity versus political capacity}

Whether or not one is willing introduce a basic income and make it a central component of our welfare states, one seems faced with a second dilemma which was neatly, though shockingly illustrated by a full-page advert published some time ago in Belgian newspapers on behalf of the (socialist) president of the Walloon government. The advert starts with a copy of a number of large cheques made out by various companies which have recently decided to settle or expand in Wallonia. The title and the punchline of the message reads "What unites us today is no longer charity but business".

Here is, then, our second dilemma. Either you try to formulate and implement your ideal of social justice in one region or in one nation, but then you soon find out that, for a number of mutually reinforcing reasons, the potential mobility of savings, investment, skilled labour and consumer demand is now such in Europe, that the only aim you can afford in all areas of policy social, educational, environmental, and so on is none other than "business", as the advert put it. The economic constraints are so powerful that you are compelled to run the State as if it were a firm and to make competitiveness your paramount concern. Or you try to give yourself some leeway by attempting to formulate and implement your ideal of social justice on a larger scale typically, for us, the European Union but then you are soon faced with the powerful obstacles that stem from a widespread distrust for highly centralized institutions, from a lack of identification and hence of spontaneous solidarity between residents of the various areas, and from the difficulty of generating a common public debate across national and linguistic boundaries about the extent and shape of the solidarity you advocate.

Is there a way out of this second dilemma? Once again, I think there is one, and one in which basic income has some role to play. I shall here make no attempt to even sketch the broad outlines of what I believe an adequate solution to this dilemma would look like. Let me just state two firm convictions to which I have been led by a close observation of the debate around the regional aspect of redistribution in Europe and in my own country, whose very existence is contingent upon the preservation of a nation-wide social security system. One is that a high level of structural redistribution across the border of broadly autonomous political entities can only be sustained if it takes the form of an interpersonal transfer system, rather than of grants to the governments of the beneficiary enttities. The other conviction is that, especially if the political entities involved are culturally and linguistically very different, such a system can only be sustained if on both the contribution and the benefit side it can operate using extremely simple and uncontroversial information. Fatal resentment is far less likely to arise, for example, if all that needs checking on the benefit side is whether a person exists and how old (s)he is, rather than whether (s)he really needs a psychiatric treatment or truly is involuntarily unemployed.

Because of the conjunction of these two convictions, I strongly believe that basic income does not only have a central role to play in solving the first dilemma of our European welfare states, but that it also has a significant role to play in tackling the second one, between the economic unsustainability of a generous national welfare state and the political unsustainability of a generous transnational welfare state. The argument sketched here would need to be elaborated and qualified along many dimensions. But I predict that as more and more people start realizing the full extent and exact nature of the two big dilemmas we face, basic income will be transformed from the pet idea of a handful of cranks who believe 
abundance has been reached at long last to a key weapon in the struggle for the preservation of social solidarity and the promotion of social justice.

\section{References}

Atkinson, Anthony B. 1993. "What is happening to the distribution of income in the UK?, STICERD Working Paper WSP/87, March 1993.

Atkinson, Anthony B. 1995. Public Economics in Action. The Basic Income / Flat Tax Proposal, Oxford: Oxford University Press.

Brittan, Samuel. 1995. Capitalism with a Human Face, Aldershot: Edward Elgar.

Gottschalk, Peter \& Joyce, Mary. 1993. "The impact of technological change, deindustrialization, and internationalization of trade on earnings inequality - An international perspective", Luxemburg Income Study, Discussion Paper 85.

Meade, James E. 1993. Liberty, Equality and Efficiency. London : Macmillan.

Milner, Dennis. 1920. Higher Production by a Bonus on National Output. A Proposal for a Minimum Income for All Varying with National Productivity. London: George Allen \& Unwin.

Paine, Thomas. 1796. "Agrarian justice", in The Life and Major Writings of Thomas Paine (P.F. Foner ed.), Secaucus (New Jersey): Citadel Press, 1974, 605-623.

Parker, Hermione. 1989. Instead of the Dole, London: Routledge \& Kegan Paul.

Van Parijs, Philippe ed. 1992. Arguing for Basic Income. Ethical Foundations for a Radical Reform. London: Verso.

Van Parijs, Philippe. 1995a. Real Freedom for All. What (if Anything) Can Justify Capitalism ?. Oxford: Oxford University Press.

Van Parijs, Philippe. 1995b. Sauver la solidarité, Paris: Editions du Cerf, forthcoming September 1995.

Van Trier, Walter. 1995. Everyone a King! An Investigation into the Meaning and Significance of the Debate on Basic Incomes with Special Reference to three Episodes from the British Inter-War Experience, Katholieke Universiteit Leuven: Fakulteit Politieke en Sociale Wetenschappen.

Walter, Tony. 1989. Basic Income. Freedom from Poverty, Freedom to Work. London: Marion Boyars. 